\title{
Emerging Trends and Old Habits in Higher Education Management: Focus on the Public vs. Private Funding Debate
}

\author{
Federico Barnabè \\ Department of Business and Social Studies, University of Siena, Siena, Italy \\ Email: barnabe@unisi.it
}

Received August 29 $9^{\text {th }}, 2012$; revised September $28^{\text {th }}, 2012$; accepted October $10^{\text {th }}, 2012$

\begin{abstract}
This work takes into consideration the wide reform process that is impacting on Universities all over the world, especially focusing on the public versus private funding debate for Higher Education Institutions. In this regard, the paper provides some considerations on possible funding sources, discusses data related to the relevance of public funding and presents the features of the main models of public funding across many countries, particularly focusing on Europe.
\end{abstract}

Keywords: Higher Education Institutions; Funding Sources; Accountability Mechanisms

\section{Preliminary Considerations}

\section{Trends and Changes within the University System}

Recently the University has been increasingly challenged to modify its traditional modus operandi and organizational structure in order to meet higher expectations coming from a large number of stakeholders and provide a wider range of products and services of higher quality (Mazza, Quattrone, \& Riccaboni, 2008).

For academic players, from the institutional level to the individual/faculty level, such process has implied a profound change and the capacity to address a variety of critical issues. Moreover, such factors have to be analysed in the light of some specific social and economic changes that have characterised modern society in European countries: demographic pressures, public spending cuts, the worldwide financial crisis are just some examples of key factors that have been impacting on the Higher Education (HE) governance system and more specifically on Higher Education Institutions (HEIs) funding system over the last two decades.

As a result, modern universities have been forced much more than in the past to develop and implement medium and long term strategies and to focalise their resources, both human and financial ones, toward the achievement of pre-defined and highly remunerative targets. Subsequently, almost everywhere, wide processes of reform have been launched. These processes have progressively changed the traditional model of the university, now become much more than in the past a sort of entrepreneurial institution, open to competition and to the market, able to sell its research and educational products within a wide and globalised context (Etzkowitz, 2003). Within this framework, a crucial point for all the countries and HEIs involved by the reforming process has been to ensure the financial sustainability of the higher education sector and its players.

More in particular, in most countries such sustainability has been pursued in coherence with a few specific objectives, including (Eurydice, 2008: p. 7):

- increasing public funding for higher education;

- granting more autonomy to institutions for managing finan- cial resources;

- establishing direct links between results and public funding allocated;

- encouraging the diversification of funding sources.

In many cases, such objectives have been pursued through a general reshuffle of the institutional governance structures in use; in other situations, some countries have developed specific policies aimed at varying the weights of funding sources.

Starting from this premise, the article provides some considerations on possible funding sources for HEIs, discusses data related to the relevance of public funding for HEIs and presents the features of the main models of public funding across many countries, specifically focusing on Europe.

\section{Impacts on University Funding Sources}

The difference between public and private funding is a relevant one and is heavily influenced by the choice between higher or lower control by governmental bodies on HEIs.

Generally, it is possible to classify national higher education systems into systems that are primarily coordinated by market interactions - "market-oriented systems"- and systems that are coordinated by governmental planning-"state-oriented systems" (Clark, 1983; Liefner, 2003).

In market-oriented systems a large proportion of funding for HEIs is provided by private actors, and competitiveness is a crucial factor for obtaining high levels of funding, simultaneously assuring qualitative teaching and research activities. The HE system in the United States and more in general in Anglo-Saxon countries is the prototype of a market-oriented system for both teaching and research activities.

On the other hand, in traditional state-coordinated systems, teaching and research activities in HE are strongly managed by government directives, and policies and university funding is mostly provided by the government. These systems are usually less innovative and responsive to changes in demand. In a few European countries it is possible to identify state-oriented systems in which governments (at least partially) plan and manage teaching and research activities as well as organizational mod- 
els and structures.

However, most national higher education systems cannot be defined as totally state-oriented or market-oriented systems, employing features of both. This is the reason why it is possible to select different forms and mechanisms of funding, evaluation and accountability when dealing with policies and strategies promoted by HEIs.

To this end, Scott (2003: p. 9) differentiates a so called metaregulatory approach, in contrast with a regulatory one. According to Scott, regulatory systems are those that set rigid prescriptions for universities, give emphasis to the measurement of results in quantitative terms and privilege rigid direct control over autonomy. However, these systems often produce undesired results, such as resistance, window-dressing and the inability to guide the subjects' behaviour towards the desired direction (e.g. see Galbraith, 1998; Geuna, 2001; Butler, 2003). By contrast, a meta-regulatory strategy provides forms of indirect control. Indirect controls can stimulate managerial and organisational skills, and guide participants towards the achievement of regulatory objectives set for each study course, department or sector. The implementation of a metaregulatory approach - in a similar way to the "soft managerialism" mentioned by Trow (1994) - may also be less costly than direct controls. Therefore, this solution could be particularly effective in academic institutions, which are traditionally viewed as loosely coupled institutions (Reponen, 1999; Czarniawska \& Genell, 2002) and are strongly characterised by their autonomy and self-regulation. It also provides the stimuli to guide the evaluated individuals towards the desired objectives, even if the latter are set by institutions outside the university.

When all these considerations are related to the selection of financial sources for HEIs and represent an input to the debate whether public or private funding is to be preferred, a wide range of models, mechanisms, performance measures and feasible strategies are to be taken into account. However, these two sources are not the only funding channels available for HEIs.

\section{Sources of University Funding}

\section{Possible Funding Sources for Higher Education Institutions}

Sources and methods of university funding are numerous and complex.

At a first glance, the main funding sources may be identified in families and students, private companies and the State. Besides these, there are various other institutions, both public and private, national and supranational (such as foundations, private non-profit institutions and supranational organisations that fund HEIs). Finally, the University can fund itself.

These sources have different weights and impacts from country to country even tough, as a general consideration, it is clear that all over the world the amount of money provided by the State is quickly decreasing whilst at the same time everywhere the University is increasingly called to explore new ways of fund raising and progressively open itself and its products to the "market".

In this regard, although it is unanimously considered that public funding still plays a key role in the growing process of the University, especially when dealing with countries that are still developing and subsequently present specific educational needs to be supported (Conceição, Heitor, \& Oliveira, 1998: pp.
204-205), a range of critical factors - both endogenous and exogenous to the University - has recently modified the availability, the weight and the function of public funding; among them, demographic pressures, public spending cuts, the overall financial crisis, new and growing expectations and demand from academic stakeholders.

This situation has pushed the University to diversify its funding sources and processes, move much more than in the past towards the market and private companies, trying to complement public funding with alternative funding sources (Wasser \& Picken, 1998). Anyhow, before examining such sources, a note on public funding should be provided.

Public funding is usually referred to as the total amount of money that the State transfer to HEIs.

The function assigned to public funding is straightforward: as stated in a document by the European Commission (Eurydice, 2008: p. 69), "the public funding mechanisms for higher education in Europe represent levers through which central governments pursue their strategic objectives within the sector". However, the debate is very open as to the opportunity-or even necessity - for HEIs to diversify their funding sources and strengthen the link between resource allocation and performance.

Overall, trying to generalise, it is clear that when considering funding allotted to universities we can refer to the total amount of resources provided either by the public sector or by the private sector; in addition to the two previous situations, the university may fund itself as portrayed in Figure 1.

Within these main sources some more specific categories of funding processes can be identified.

- The first category refers to a situation in which the funding process has as its source a governmental body, usually the Ministry of Education. The funds allotted to the University are provided on the basis of a specific methodology. The University may be not restricted in any specific use to which the funds are distributed, only carrying out activities in order to contribute towards the attainment of general political, economic and social goals. Alternatively, funding may be provided by a governmental body as well, but in this case a detailed series of rules and procedures is imposed upon the use of the resources provided to the University. Last, the university can be funded by a variety of government bodies and public institutions, including, as an example, local and regional governments.

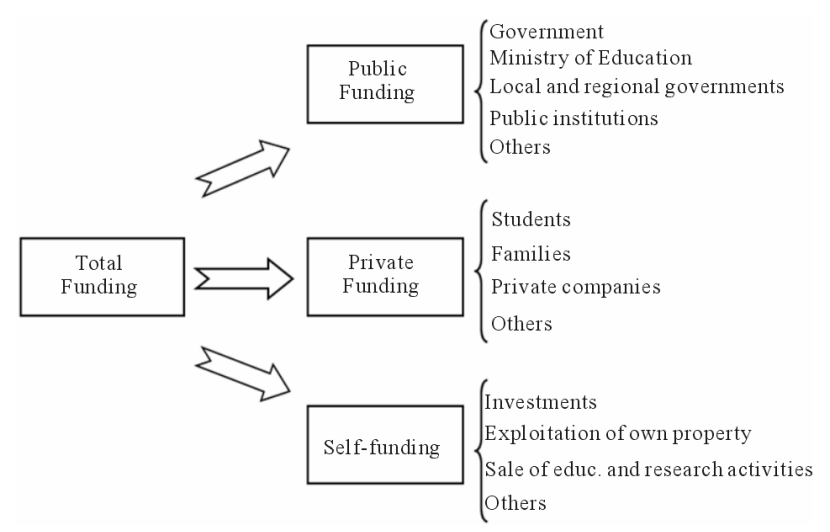

Figure 1.

Main funding sources for HEIs. 
- In the second case, HEIs are funded with private financial sources, mostly provided by the students and their families, and by private companies.

- The university may also fund itself by means of its investments and the exploitation of its property (both fixed and intellectual), thus ensuring an independent source of money. Furthermore, within this case it is possible to refer to the sale (in a strict commercial sense) by the university of educational and research activities.

All these distinct categories of funding processes correspond to different combinations of the source of funding, the mechanism by which funding is awarded and provided, conditions in the use of funding and the justification for funding.

In so doing, it should be carefully noted that university funding is generally considered from the point of view of the "university system" (Caraça, Conceição, \& Heitor, 1998: p. 37) whilst the point of view of the single academic institution is frequently overlooked or ignored.

Subsequently, the following table clarifies how educational expenditure can be financed, differentiating between public and private sources of funds plus private funds publicly subsidised, and between spending on education inside or outside educational institutions. Examples of goods and services usually purchased thanks to those specific forms of funds are provided.

Table 1 allows to generalize and classify educational expenditure through three dimensions:

1) the first dimension, represented by the horizontal axis, relates where expenditure occurs, i.e. distinguishing between expenditure within or outside educational institutions, such as universities;

2) the second dimension refers to the goods and services that are purchased. This dimension is represented by the vertical axis;

3 ) the third dimension is represented by the capital letters used in the diagram, distinguishing the different sources of funding among public sources of funds (A), private sources of funds (B) or private funds publicly subsidised (C).

Such categorisation certainly provides a more comprehensive picture of education systems and possible funding sources. However, it still fails to estimate the weights of such sources, i.e. whether those typologies of expenditures are primarily financed by public funding or on the contrary by other funding sources.

According to the a large part of the literature, public funding (and more in particular direct public funding) still represents a relevant share of the total higher education funding and in most countries HEIs would not be able to provide educational services and products without a massive support from governments and public authorities, in the form of direct or indirect public funding.

On the basis of the previous considerations, a more in depth analysis is helpful and some key questions should be addressed, as follows:

- Which is the role played by public funding within the HE system of several countries?

- How does resource allocation vary among the higher education systems of several nations and which are the most widely used methodologies of resource allocation?

- More specifically, which are the most common methods used by HEIs to internally allocate their resources? And subsequently, which are the most common and feasible accountability mechanisms for the use of funding?

- Which are the main destinations of public funding?

\section{The Relevance of Public Funding for Higher Education in Europe}

In the previous sections we highlighted that education ex-

Table 1.

Classification of educational expenditure.

\begin{tabular}{|c|c|c|}
\hline & $\begin{array}{l}\text { Spending on educational institutions } \\
\text { (e.g. schools, universities, educational administration and } \\
\text { student welfare services) }\end{array}$ & $\begin{array}{l}\text { Spending on education outside educational institutions } \\
\text { (e.g. private purchases of educational goods and services, } \\
\text { including private tutoring) }\end{array}$ \\
\hline \multirow{6}{*}{$\begin{array}{l}\text { Spending on core educational } \\
\text { services }\end{array}$} & $\begin{array}{l}\text { (A) } \\
\text { e.g. public spending on instructional services in } \\
\text { educational institutions }\end{array}$ & $\begin{array}{l}\text { (C) } \\
\text { e.g. subsidised private spending on books }\end{array}$ \\
\hline & (C) & \multirow{5}{*}{$\begin{array}{l}\text { (B) } \\
\text { e.g. private spending on books and other school materials } \\
\text { or private tutoring }\end{array}$} \\
\hline & e.g. subsidised private spending on instructional services & \\
\hline & in educational institutions & \\
\hline & (B) & \\
\hline & e.g. private spending on tuition fees & \\
\hline \multirow{4}{*}{$\begin{array}{l}\text { Spending on research and } \\
\text { development }\end{array}$} & (A) & \\
\hline & e.g. public spending on university research & \\
\hline & (B) & \\
\hline & $\begin{array}{l}\text { e.g. funds from private industry for research and } \\
\text { development in educational institutions }\end{array}$ & \\
\hline \multirow{4}{*}{$\begin{array}{l}\text { Spending on educational } \\
\text { services other than instruction }\end{array}$} & (A) & (C) \\
\hline & $\begin{array}{l}\text { e.g. public spending on ancillary services such as meals, } \\
\text { transport to schools, or housing on the campus }\end{array}$ & $\begin{array}{l}\text { e.g. subsidised private spending on student living costs or } \\
\text { reduced prices for transport }\end{array}$ \\
\hline & (B) & (B) \\
\hline & e.g. private spending on fees for ancillary services & e.g. private spending on student living costs or transport \\
\hline
\end{tabular}

Legenda: A = Public sources of funds; B = Private sources of funds; C = Private funds publicly subsidized; Source: Adapted from OECD (2011: p. 204). 


\section{F. BARNABÈ}

penditure is basically financed by a few distinct forms of funding and mainly by public and private funding. Moreover, we stressed that both public and private funding are necessary to cover HE expenditures, for example when dealing with expenditures related to R\&D. Additional data are consequently helpful in providing some evidence.

First of all, taking into consideration Gross Domestic Expenditure on $R \& D$, it is clear that HE still represents a relevant sector for private and public investments, as shown in Table 2.

In this scenario, HEIs play a central role. However, their functions go far beyond R\&D activities. It is the very essence of HEIs and their educational mission that represent the main rationale to their own existence: create and transfer new knowledge and manage public goods in their educational services and products. In this regard, it is to note that funding to
HEIs is needed to cover a wide range of expenditures, from current expenditures, to investments and specific (research and teaching) projects.

Overall, some additional information can be provided taking into consideration the following table that represents the relative proportions (as a \%) of public and private expenditure on educational institutions, for tertiary education and for a selection of OECD countries.

Table 3 clarifies which are the main funding sources for tertiary education across the world. It is straightforward to identify relative weights and sources of funding. As said, although HEIs are increasingly differentiating their funding sources and have been increasingly challenged to find new financing entities, public funding (and more in particular direct public funding) counts for a substantial share of the higher education budget.

Table 2.

Gross domestic expenditure on R\&D (2008).

\begin{tabular}{cccccccc}
\hline & & \multicolumn{2}{c}{$\%$} & & \% performed by & \multicolumn{2}{c}{ Total researchers 2007 } \\
\hline Country & Million current PPP\$ & Industry & Government & Industry & Higher education & Government & Full time equivalent \\
\hline EU-27 & $262,985.0$ & 55.0 & 34.1 & 63.4 & 21.8 & 13.7 & 1360,332 \\
Total OECD & $886,347.1$ & 63.8 & 28.6 & 69.6 & 16.8 & 11.1 & 3997,466 \\
\hline
\end{tabular}

Source: OECD/OCDE (2009: p. 1).

Table 3.

Distribution of public and private sources of funds for educational institutions after transfers from public sources, by year.

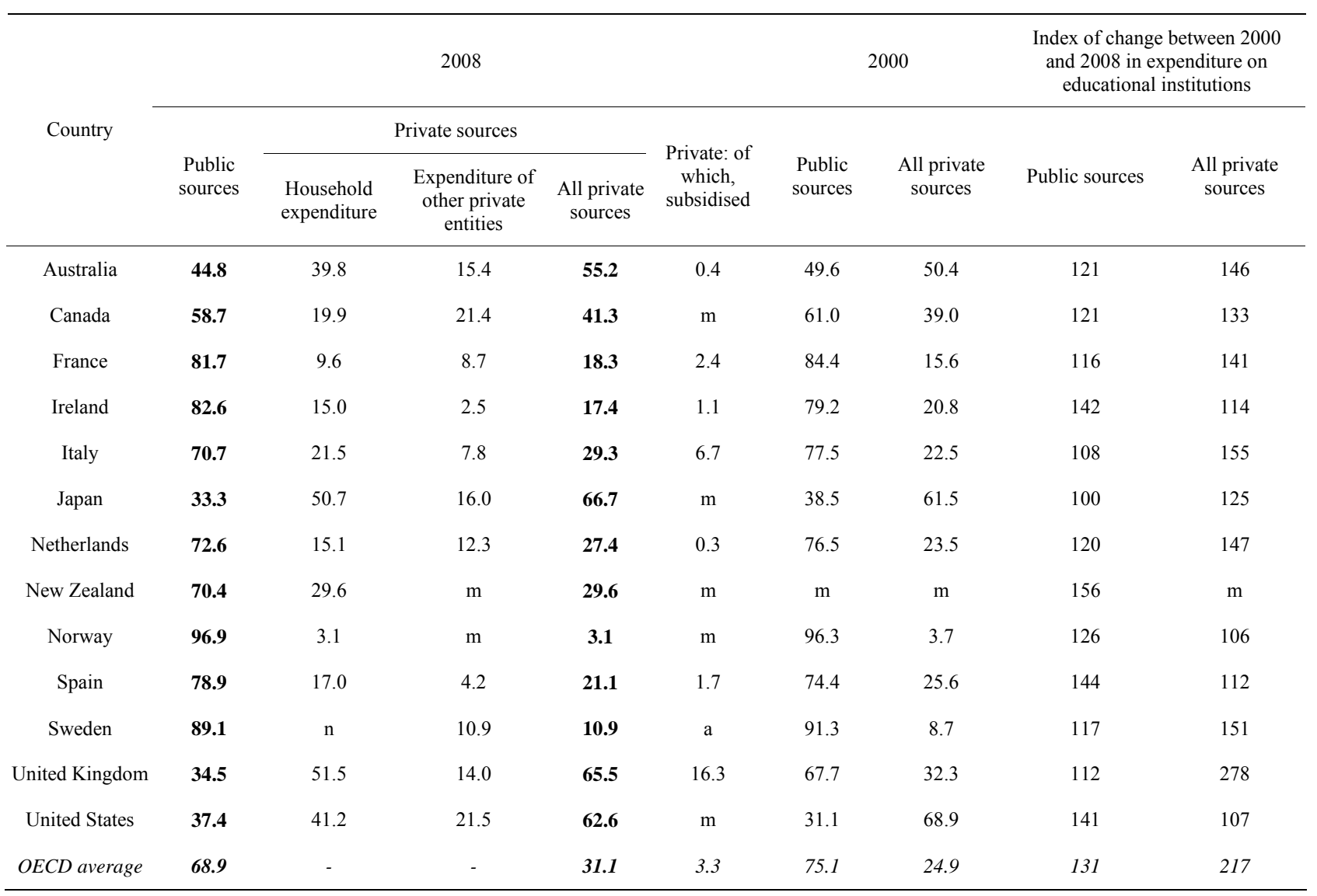

Legenda: $\mathrm{a}=$ Data is not applicable because the category does not apply; $\mathrm{m}=$ Data is not available; $\mathrm{n}=$ Magnitude is either negligible or zero. Source: OECD (2011: $\mathrm{p}$. 244). 


\section{F. BARNABÈ}

Even more evident are the data comparing the proportion of educational expenditure from public and private sources. Note that public expenditure includes all direct purchasing of education resources by the public sector (at whatever administrative level), whereas private expenditure includes the payment of tuition fees (and all other payments) primarily by households, businesses and non-profit associations. These data are provided in Table 4 for the EU countries.

As shown in Table 4, education expenditure is mostly financed by public funding that in most of the cases represents more than $80 \%$ of education expenditure and is $86.2 \%$ on average. However, some differences are evident among EU coun- tries and these divergences can depend upon a variety of exogenous or endogenous factors as well as cultural, political and geographical elements.

Furthermore, on the whole financial cuts and governmental reforms are shifting the burden of financing educational expenditure on HEIs themselves more than on the governments and tax payers. In this regard, the data for several OECD countries allow to identify clear downward trends in relative proportions of public expenditures on educational institutions, as shown in Table 5.

In sum, overall it is plain the role of public funding even though with a decreasing relevance.

Table 4.

Proportions of educational expenditure from public and private sources, 2008.

\begin{tabular}{|c|c|c|c|c|c|c|c|c|c|}
\hline Country & $\mathrm{EU}$ & $\mathrm{BE}$ & BG & $\mathrm{CZ}$ & DK & $\mathrm{DE}$ & $\mathrm{EE}$ & IE & EL \\
\hline Public funding & 86.2 & 94.3 & 87.2 & 87.3 & 92.2 & 85.4 & 94.7 & 93.8 & $:$ \\
\hline \multirow[t]{2}{*}{ Private funding } & 13.8 & 5.7 & 12.8 & 12.7 & 7.8 & 14.6 & 5.3 & 6.2 & $:$ \\
\hline & ES & FR & IT & $\mathrm{CY}$ & LV & LT & $\mathrm{LU}$ & $\mathrm{HU}$ & MT \\
\hline Public funding & 87.1 & 90.0 & 91.4 & 82.7 & 90.1 & 90.1 & : & : & 95.0 \\
\hline \multirow[t]{2}{*}{ Private funding } & 12.9 & 10.0 & 8.6 & 17.3 & 9.9 & 9.9 & : & : & 5.0 \\
\hline & NL & $\mathrm{AT}$ & PL & PT & RO & SI & SK & FI & $\mathrm{SE}$ \\
\hline Public funding & 83.6 & 90.8 & 87.1 & 90.5 & : & 88.4 & 82.5 & 97.4 & 97.3 \\
\hline \multirow[t]{2}{*}{ Private funding } & 16.4 & 9.2 & 12.9 & 9.5 & : & 11.6 & 17.5 & 2.6 & 2.7 \\
\hline & UK & IS & LI & NO & $\mathrm{CH}$ & $\mathrm{HR}$ & $\mathrm{TR}$ & & \\
\hline Public funding & 69.5 & 90.0 & $:$ & 98.2 & 90.3 & 92.2 & $:$ & & \\
\hline Private funding & 30.5 & 9.1 & : & 1.8 & 9.7 & 7.8 & : & & \\
\hline
\end{tabular}

Source: Eurostat (2012: p. 93).

Table 5.

Trends in relative proportions of public expenditure on educational institutions, for tertiary education, $1995-2008$.

\begin{tabular}{|c|c|c|c|c|c|c|c|c|c|}
\hline \multirow{2}{*}{ Country } & \multicolumn{9}{|c|}{ Share of public expenditure on educational institutions (\%) } \\
\hline & 1995 & 2000 & 2002 & 2003 & 2004 & 2005 & 2006 & 2007 & 2008 \\
\hline Australia & 64.8 & 51.0 & 48.7 & 48.0 & 47.2 & 47.8 & 47.6 & 44.3 & 44.8 \\
\hline Canada & 56.6 & 61.0 & 56.4 & $\mathrm{~m}$ & 55.1 & 53.4 & $\mathrm{~m}$ & 58.7 & $\mathrm{~m}$ \\
\hline Finland & 97.8 & 97.2 & 96.3 & 96.4 & 96.3 & 96.1 & 95.5 & 95.7 & 95.4 \\
\hline France & 85.3 & 84.4 & 83.8 & 83.8 & 83.8 & 83.6 & 83.7 & 84.5 & 82.7 \\
\hline Germany & 89.2 & 88.2 & $\mathrm{~m}$ & $\mathrm{~m}$ & $\mathrm{~m}$ & 85.3 & 85.0 & 84.7 & 85.4 \\
\hline Ireland & 69.7 & 79.2 & 85.8 & 83.8 & 82.6 & 84.0 & 85.1 & 85.4 & 82.6 \\
\hline Italy & 82.9 & 77.5 & 78.6 & 72.1 & 69.4 & 69.6 & 73.0 & 51.6 & 51.3 \\
\hline Japan & 35.1 & 38.5 & 35.3 & 36.6 & 36.6 & 33.7 & 32.2 & 32.5 & 33.3 \\
\hline Netherlands & 79.4 & 76.5 & 74.9 & 74.4 & 75.0 & 73.3 & 73.4 & 72.4 & 72.6 \\
\hline Norway & 93.7 & 96.3 & 96.3 & 96.7 & $\mathrm{~m}$ & $\mathrm{~m}$ & 97.0 & 97.0 & 96.9 \\
\hline Spain & 74.4 & 74.4 & 76.3 & 76.9 & 75.9 & 77.9 & 78.2 & 79.0 & 78.9 \\
\hline Sweden & 93.6 & 91.3 & 90.0 & 89.0 & 88.4 & 88.2 & 89.1 & 89.3 & 89.1 \\
\hline United Kingdom & 80.0 & 67.7 & 72.0 & 70.2 & 69.6 & 66.9 & 64.8 & 35.8 & 34.5 \\
\hline United States & 37.4 & 31.1 & 39.5 & 38.3 & 35.4 & 34.7 & 34.0 & 31.6 & 37.4 \\
\hline OECD average & 79.7 & 77.8 & 76.0 & 76.5 & 74.2 & 72.8 & 73.3 & 69.1 & 69.3 \\
\hline
\end{tabular}

Legenda: $\mathrm{m}=$ Data is not available. Source: Adapted from OECD (2009: p. 234) for 1995-2006 and OECD (2011: p. 245) for 2007-2008. 
In order to develop a more in depth analysis, at least three key elements should be further discussed: types of grants, accountability mechanisms for the use of funding and destinations of public funding. These factors are discussed afterwards.

\section{Models and Features of Public Funding in Europe}

\section{Types of Grant}

Across Europe, HEIs generally receive block grants meant to cover several categories of expenditures. In most countries, block grants are subsequently divided between categories of expenditure depending on the internal governance of the institution concerned, whilst only in a few countries block grants are allocated under expenditure headings that have to be strictly complied with. Overall, in the majority of cases block grants are intended to cover teaching and ongoing operational expenditure.

It is to note that block grants do not represent the only source of public funding, since in many countries HEIs receive public funding linked to specific objectives and purposes: it is the case of investment schemes linked to national programmes, social objectives and research programmes.

Coming to the funding mechanisms, the main typologies that are in use across Europe are the following ones.

1) Budget negotiation with the funding body based on a budget estimate submitted by the institution. or budget established by the funding body based on past costs.

2) Funding formulas. They are tools used to calculate the amount of public grants for teaching and/or ongoing operational activity. In some cases they could also take into consideration research activity. The rationale behind the use of funding formulas is clear: they are considered to be feasible ways of increasing the transparency of public funding by allocating funds objectively among HEIs, also avoiding other pressures (such as political ones). Usually, these formulas rely on input criteria and therefore are based on the volume of institutional activities, which is very often measured as the number of students enrolled at the institution. It is also to note that in many cases funding formulas take into consideration performance criteria, which are related to the outputs achieved by a specific HEI over a previous period (e.g. student success rate).

3) Performance contracts, having the aim to clearly define objectives in line with national priorities; thus, a share of public funding is allocated to HEIs depending on these contracts which basically represent a way to measure whether institutions actually achieve their targets. Although the use of these contracts seems to widely vary across countries, they represent useful incentives for HEIs to simultaneously pursue individual and national strategic objectives.

4) Contracts based on a predetermined number of graduates by field of study. In other words, contracts between HEIs and public authorities are meant to ensure a certain number of students graduated by the end of a given period in particular subjects or field of study.

5) Funding for specific research projects, awarded in the framework of competitive building procedures. It is to note that in the majority of countries where HEIs receive funds for research and development, public funds are provided under a dual system based on basic funding for research, which is used for purposes determined by the HEIs, or on public funding awarded on a competitive basis for specific schemes or research programmes. These two solutions also differ in reference to the criteria adopted in order to allocate funds: in basic funding for research, countries usually rely on inputs (e.g. costs of research activities carried out) and/or performance measures (e.g. number of academic publications or amount of public and private funding obtained); for public funding allocated on a competitive basis, very often peer evaluation procedures and performance criteria are used (e.g. see the Research Assessment Exercise in U.K.).

European Commission's data allow not only to gain a comprehensive picture related to Member Countries but also to stress which changes have been made over the last few years, thus further testifying the process of reform we referred to.

In this regard, Table 6 represents the situation at 2007, whilst Table 7 offers a more recent analysis.

As shown, the most widely used mechanism in 2006-07 was the funding formula, even though the relative importance of this mechanism with respect to other ones varied according to country, as shown in Figure 2.

As said, however, over the last few years many changes have been made to funding schemes across Europe, with the relative composition of funding mechanisms that was consequently further modified, as shown in Table 7.

\section{Accountability Mechanisms for the Use of Funding and Main Destinations of Public Funding}

As clarified in the previous section, very often public funding is allocated to HEIs in the form of block grants. On their side, HEIs usually have a high degree of autonomy in selecting the destinations of such funds and block grants are consequently destined to cover many types of expenditures. In particular, as to monitoring institutions for the use of public funding, it is to stress that HEIs in Europe seem to be quite free to use as they prefer public funding at their disposal.

This situation is particularly verified when HEIs are awarded block grants covering different categories of expenditure.

However, it is well known that autonomy has to be matched with accountability.

Therefore, specific forms of monitoring the use of funding as well as the introduction of accountability measures seem to be necessary in order to enable the public authorities and other

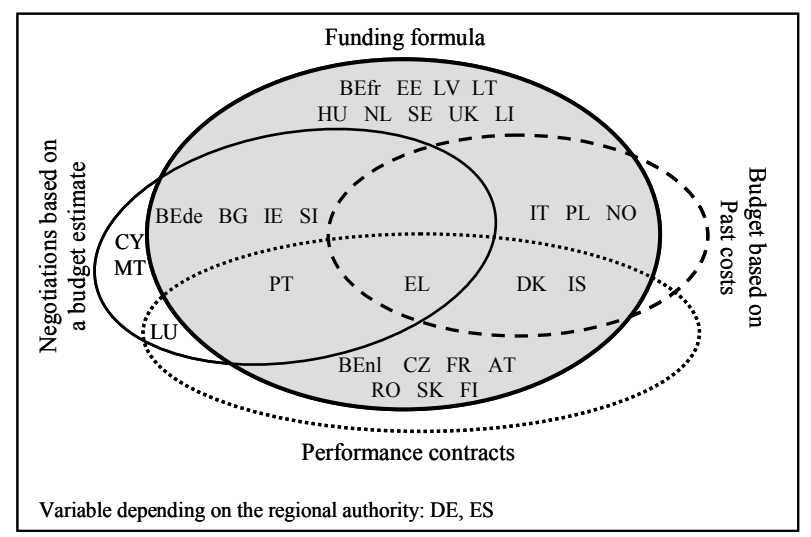

Figure 2.

Overview of the public funding mechanisms, public and governmentdependent private higher education, 2006-07. Source: Eurydice (2008: p. 70). 


\section{F. BARNABÈ}

Table 6.

Main mechanisms for direct public funding, public and government-dependent private higher education, 2006-07.

\begin{tabular}{|c|c|c|c|c|c|c|c|c|c|c|c|c|c|c|c|c|c|}
\hline & $\mathrm{BE}$ fr & $\mathrm{BE}$ de & $\mathrm{BE} \mathrm{nl}$ & BG & $\mathrm{CZ}$ & DK & $\mathrm{DE}$ & $\mathrm{EE}$ & IE & EL & ES & FR & IT & CY & LV & LT & LU \\
\hline $\begin{array}{l}\text { Budget negotiation with the } \\
\text { funding body }\end{array}$ & & $\bullet$ & & $\bullet$ & & & & & $\bullet$ & $\bullet$ & & & & $\bullet$ & & & $\bullet$ \\
\hline Budget based on past costs & & & & & & $\bullet$ & & & & $\bullet$ & & & $\bullet$ & & & & \\
\hline Funding formula & $\bullet$ & $\bullet$ & $\bullet$ & $\bullet$ & $\bullet$ & $\bullet$ & & $\bullet$ & $\bullet$ & $\bullet$ & & $\bullet$ & $\bullet$ & & $\bullet$ & $\bullet$ & \\
\hline $\begin{array}{l}\text { Performance contracts based on } \\
\text { strategic objectives }\end{array}$ & & & $\bullet$ & & $\bullet$ & $\bullet$ & $\circ$ & & & $\bullet$ & $\circ$ & $\bullet$ & & & & & • \\
\hline $\begin{array}{l}\text { Contracts based on a predetermined } \\
\text { number of graduates }\end{array}$ & & & & & & & & $\bullet$ & & & & & & & $\bullet$ & & \\
\hline \multirow[t]{2}{*}{$\begin{array}{l}\text { Funding for specific research } \\
\text { projects, }\end{array}$} & $\bullet$ & $\bullet$ & $\bullet$ & $\bullet$ & $\bullet$ & $\bullet$ & & $\bullet$ & $\bullet$ & $\bullet$ & & & $\bullet$ & & $\bullet$ & & n.a. \\
\hline & $\mathrm{HU}$ & MT & NL & AT & PL & PT & $\mathrm{RO}$ & SI & SK & FI & SE & $\begin{array}{l}\mathrm{UK} \\
/ \mathrm{WL}\end{array}$ & $\begin{array}{l}\text { ENG } \\
\text { SNIR }\end{array}$ & UK-SCT & IS & LI & $\mathrm{NO}$ \\
\hline $\begin{array}{l}\text { Budget negotiation with the } \\
\text { funding body }\end{array}$ & & $\bullet$ & & & & $\bullet$ & & $\bullet$ & & & & & & & & & \\
\hline Budget based on past costs & & & & & $\bullet$ & & & & & & & & & & $\bullet$ & & $\bullet$ \\
\hline Funding formula & $\bullet$ & & $\bullet$ & $\bullet$ & $\bullet$ & $\bullet$ & $\bullet$ & $\bullet$ & $\bullet$ & $\bullet$ & $\bullet$ & & b & $\bullet$ & $\bullet$ & $\bullet$ & $\bullet$ \\
\hline $\begin{array}{l}\text { Performance contracts based on } \\
\text { strategic objectives }\end{array}$ & & & & $\bullet$ & & $\bullet$ & $\bullet$ & & $\bullet$ & $\bullet$ & & & & & $\bullet$ & & \\
\hline \multicolumn{18}{|l|}{$\begin{array}{l}\text { Contracts based on a } \\
\text { predetermined number of graduates }\end{array}$} \\
\hline $\begin{array}{l}\text { Funding for specific research } \\
\text { projects }\end{array}$ & $\bullet$ & $\bullet$ & $\bullet$ & $\bullet$ & $\bullet$ & $\bullet$ & $\bullet$ & $\bullet$ & $\bullet$ & $\bullet$ & $\bullet$ & & 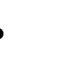 & $\bullet$ & $\bullet$ & $\bullet$ & $\bullet$ \\
\hline
\end{tabular}

Table 7.

Main funding mechanisms for European HEIs, 2011.

\begin{tabular}{|c|c|c|c|c|c|c|c|c|c|c|c|c|c|c|c|c|c|}
\hline & $\mathrm{BE}$ fr & $\mathrm{BE}$ de & $\mathrm{BE} \mathrm{nl}$ & BG & $\mathrm{CZ}$ & DK & $\mathrm{DE}$ & $\mathrm{EE}$ & IE & EL & ES & FR & IT & $\mathrm{CY}$ & LV & $\mathrm{LT}$ & $\mathrm{LU}$ \\
\hline Negotiated allocation & & & & $\bullet$ & & & $:$ & & & & & & & & & & $:$ \\
\hline Purpose-specific funding & $\bullet$ & & & & $\bullet$ & & : & & & & & & & & & $\bullet$ & : \\
\hline $\begin{array}{l}\text { Performance-based } \\
\text { mechanisms }\end{array}$ & & & $\bullet$ & & & $\bullet$ & $:$ & & & $\bullet$ & & & & & $\bullet$ & & $:$ \\
\hline Input-based mechanism & & $\bullet$ & $\bullet$ & & $\bullet$ & & : & & $\bullet$ & & $\bullet$ & & $\bullet$ & $\bullet$ & & $\bullet$ & $:$ \\
\hline \multirow[t]{2}{*}{ Other } & $\bullet$ & & & & & & $:$ & $\bullet$ & & & & $\bullet$ & & & & & $:$ \\
\hline & $\mathrm{HU}$ & MT & NL & AT & PL & $\mathrm{PT}$ & $\mathrm{RO}$ & SI & SK & FI & $\mathrm{SE}$ & $\begin{array}{l}\text { UK-ENG } \\
\text { /WLS/NIR }\end{array}$ & UK-SCT & IS & LI & NO & TR \\
\hline Negotiated allocation & & $\bullet$ & : & $\bullet$ & & $:$ & $\bullet$ & & & $\bullet$ & & $\bullet$ & $\bullet$ & $\bullet$ & $\bullet$ & & $\bullet$ \\
\hline Purpose-specific funding & & & : & & $\bullet$ & : & $\bullet$ & & $\bullet$ & & & $\bullet$ & $\bullet$ & & & $\bullet$ & \\
\hline $\begin{array}{l}\text { Performance-based } \\
\text { mechanisms }\end{array}$ & & & : & & & : & $\bullet$ & $\bullet$ & $\bullet$ & & $\bullet$ & $\bullet$ & & $\bullet$ & & $\bullet$ & \\
\hline Input-based mechanism & $\bullet$ & & : & & & : & & $\bullet$ & & & $\bullet$ & $\bullet$ & & & & & \\
\hline Other & & & : & & & : & & & & & & & & & & & \\
\hline
\end{tabular}

Source: Eurydice (2012: p. 38).

stakeholders to perform desired control and design financial and strategic policies. Moreover, accountability measures would serve as a reliable and useful regulating mechanism to assure institutional autonomy. Common forms of accountability measures and mechanisms include financial audits, performance indicators, annual reports, production of information databases, and publication of internal evaluation results.
European Commission's data allow to present the following picture related to Member Countries.

As shown by the Table 8, financial audits are a quite common way of ensuring accountability. Such audits can be carried out by independent external bodies (e.g. a national or regional body) or can be performed internally by the HEIs themselves.

Performance indicators are a second common way to ensure 
Table 8.

Accountability measures in relation to use of public funding, public and government-dependent private higher education, 2006-07.

\begin{tabular}{|c|c|c|c|c|c|c|c|c|c|c|c|c|c|c|c|c|}
\hline & $\mathrm{BE}$ fr & BE de & $\mathrm{BE} \mathrm{nl}$ & BG & $\mathrm{CZ}$ & DK & $\mathrm{DE}$ & $\mathrm{EE}$ & IE & EL & ES & FR & $\mathrm{CY}$ & LV & LT & $\mathrm{LU}$ \\
\hline $\begin{array}{l}\text { Compulsory external } \\
\text { financial audits }\end{array}$ & $\bullet$ & $\bullet$ & $\bullet$ & $\bullet$ & $\bullet$ & $\bullet$ & & $\bullet$ & $\bullet$ & $\bullet$ & & $\bullet$ & $\bullet$ & $\bullet$ & $\bullet$ & $\bullet$ \\
\hline $\begin{array}{l}\text { Compulsory internal } \\
\text { financial audits }\end{array}$ & & & & & $\bullet$ & & & • & $\bullet$ & $\bullet$ & & & & & $\bullet$ & \\
\hline $\begin{array}{l}\text { Public funding related to } \\
\text { performance indicators }\end{array}$ & & & $\bullet$ & & $\bullet$ & $\bullet$ & $\circ$ & • & $\bullet$ & • & $\circ$ & $\bullet$ & & • & • & \\
\hline \multirow{2}{*}{$\begin{array}{l}\text { Public funding related to the } \\
\text { fulfillment of institutional } \\
\text { strategic plans/objectives }\end{array}$} & & & & $\bullet$ & $\bullet$ & & & & $\bullet$ & & & $\bullet$ & & & & \\
\hline & $\mathrm{HU}$ & MT & $\mathrm{NL}$ & AT & PL & PT & RO & SI & SK & FI & SE & $\begin{array}{l}\text { UK-ENG } \\
\text { /WLS/NIR }\end{array}$ & UK-SCT & IS & LI & $\mathrm{NO}$ \\
\hline $\begin{array}{l}\text { Compulsory external } \\
\text { financial audits }\end{array}$ & $\bullet$ & • & $\bullet$ & $\bullet$ & $\bullet$ & $\bullet$ & $\bullet$ & $\bullet$ & $\bullet$ & $\bullet$ & $\bullet$ & $\bullet$ & $\bullet$ & $\bullet$ & $\bullet$ & $\bullet$ \\
\hline $\begin{array}{l}\text { Compulsory internal } \\
\text { financial audits }\end{array}$ & $\bullet$ & $\bullet$ & $\bullet$ & & $\bullet$ & & $\bullet$ & & & $\bullet$ & $\bullet$ & $\bullet$ & & & & \\
\hline $\begin{array}{l}\text { Public funding related to } \\
\text { performance indicators }\end{array}$ & $\bullet$ & & $\bullet$ & $\bullet$ & $\bullet$ & $\bullet$ & $\bullet$ & $\bullet$ & $\bullet$ & $\bullet$ & $\bullet$ & $\bullet$ & $\bullet$ & $\bullet$ & $\bullet$ & $\bullet$ \\
\hline $\begin{array}{l}\text { Public funding related to the } \\
\text { fulfillment of institutional } \\
\text { strategic plans/objectives }\end{array}$ & & & & & & & & $\bullet$ & & $\bullet$ & & $\bullet$ & & & & \\
\hline
\end{tabular}

Legenda: • = Accountability measure used; $\circ=$ Variable depending on the regional authority. Source: Eurydice (2008: p. 64).

accountability. Many countries are held accountable for their use of public funding by linking at least a part of the amount to performance, obviously with different weights for such measures into the funding formulas used to calculate the public block grants and research grants.

Last, in almost all countries institutional strategic plans are compulsory. Therefore, they represent a useful tool not only to measure the institutional accomplishments, but also to influence the allocation of public funding to each HEI.

As to the main destinations of public funding, the expenditures by educational institutions can be classified into two main categories: current expenditure and capital expenditure.

Overall, current expenditure is the largest one, including cost items such as wages and costs relating to staff, costs of maintaining buildings, purchasing educational materials and operational resources. Among these, staff expenditure represents the largest cost item, being an average of $70 \%$ of annual expenditure in the EU, as portrayed in Table 9.

As shown, current expenditure weights for more than $91 \%$ on the total amount of expenditure by public sector institutions in almost all the EU countries, thus demonstrating a high degree of homogeneity across Europe. On the contrary, more significant differences can be found taking into consideration the relative proportion of capital expenditure in each country.

\section{Discussion and Final Remarks on Changes in University Public Funding}

From the information and considerations provided in the previous sections, it is clear that HE funding sources have been differentiated across different countries in the last decades.

This process has happened in concomitance with the passage from the elite university system to the "mass higher education" and within a context increasingly characterised by cuts and rationalizations in public expenditures and funding. In many countries these factors fundamentally led to two situations:

a) the diversification of funding sources for HEIs, with an increased relevance given to private funding and a higher emphasis placed on the capacity of universities to exploit their own capital and knowledge;

b) the diversification of public funding procedures and allocation mechanisms, more often than in the past linked to performance and oriented towards competition among universities and HE systems.

In this scenario, HEIs can be currently viewed as cost-sharing systems (Johnstone, 2004) in which at least four principal parties co-participate in financing universities and higher education activities: the government or taxpayers, parents, students and individual or institutional donors. Across different countries the tendency towards cost-sharing seems to be clear, being caused by specific phenomena such as the dramatic increase in the number of students over the last three decades, the substantial decrease in direct public funding to universities, the enormous pressures upon academic institutions to provide qualitative research and teaching outputs, the higher costs of higher education (both per unit and per student costs). However, even though cost-sharing and funding diversification seem rational and in some way foreseeable events, they are still controversial and under debate.

In particular, the decision of most governments to grant more autonomy to institutions (not only for managing financial resources but also in terms of statutory and managerial autonomy) has pushed HE systems and HEIs toward a greater diversification of funding sources, the establishment of more direct links between results and the amount of funds allocated, the creation of partnerships between HEIs and private businesses, research institutes and regional authorities, the exploitation of their own properties. In brief, it seems that the university is rapidly 
Table 9.

Distribution of total annual expenditure in public sector institutions across major categories of expenditure, 2008.

\begin{tabular}{|c|c|c|c|c|c|c|c|c|c|c|c|c|c|c|c|c|c|}
\hline & $\mathrm{EU}$ & $\mathrm{BE}$ & BG & $\mathrm{CZ}$ & DK & $\mathrm{DE}$ & $\mathrm{EE}$ & IE & EL & ES & FR & IT & $\mathrm{CY}$ & LV & LT & $\mathrm{LU}$ & $\mathrm{HU}$ \\
\hline Capital & 8.9 & 4.1 & 14.0 & 10.0 & 5.3 & 7.6 & : & 9.2 & : & 12.5 & 9.5 & 5.9 & 14.9 & 15.8 & 9.0 & : & 5.8 \\
\hline $\begin{array}{c}\text { Current } \\
\text { expenditure-Staff }\end{array}$ & 70.2 & 82.3 & 60.6 & 53.2 & 77.0 & 71.3 & : & 72.9 & : & 70.4 & 73.6 & 74.7 & 73.0 & 65.9 & 71.4 & : & 69.0 \\
\hline \multirow[t]{2}{*}{$\begin{array}{c}\text { Current } \\
\text { expenditure-Other }\end{array}$} & 20.8 & 13.6 & 25.5 & 36.8 & 17.7 & 21.1 & : & 18.0 & : & 17.1 & 16.9 & 19.4 & 12.0 & 18.3 & 19.6 & : & 25.2 \\
\hline & MT & $\mathrm{NL}$ & $\mathrm{AT}$ & PL & $\mathrm{PT}$ & RO & SI & SK & FI & $\mathrm{SE}$ & UK & IS & LI & NO & $\mathrm{CH}$ & HR & $\mathrm{TR}$ \\
\hline Capital & 8.0 & 13.6 & : & 8.0 & 3.5 & : & 11.1 & 4.7 & 7.1 & 5.9 & 8.3 & 8.1 & : & 11.3 & 7.8 & 3.4 & $:$ \\
\hline $\begin{array}{c}\text { Current } \\
\text { expenditure-Staff }\end{array}$ & 71.6 & 67.7 & : & 60.5 & 84.2 & : & 67.2 & 57.7 & 59.9 & 63.5 & 71.5 & 68.7 & 69.8 & 66.6 & 76.6 & 61.2 & $:$ \\
\hline $\begin{array}{c}\text { Current } \\
\text { expenditure-Other }\end{array}$ & 20.4 & 18.7 & : & 31.5 & 12.3 & : & 21.7 & 37.6 & 33.0 & 30.5 & 20.2 & 23.3 & 30.2 & 22.1 & 15.6 & 35.4 & $:$ \\
\hline
\end{tabular}

Source: Eurostat (2012: p. 95).

changing: from ivory towers, universities are quickly becoming entrepreneurial institutions, open to the market and in competition for financial resources, staff and students (see Barry, Chandler, \& Clark, 2001; Etzkowitz, Webster, Gebhardt, \& Terra, 2000).

However, a completely shared and common view on which funding solution is the best way is still to be identified. In particular, if on one hand the entrepreneurial model of university were to be adopted and consequently an increasing degree of autonomy and freedom to collect their own financial resources should be granted to HEIs, on the other hand part of the literature still underlines the need and relevance of public funding to universities, especially when considering developing or in "late-comers" countries.

Therefore, as Barr (1993: pp. 719-720) and other scholars point out, some key questions should be raised in considering the "public vs. private funding to HE" debate. Among them:

- should higher education be centrally planned?

- how should student loans be designed?

- should higher education be subsidised?

And, subsequently:

- which should be the proportion between public and private funding to universities?

- which accountability mechanisms on the use of funding should be strengthened?

- how to further stimulate competition among universities, also in regard to their fund raising functions?

- how to further stimulate the diversification of funding sources for HEIs?

The answers to these questions should help in addressing the issue related to whether and/or to what extent universities and HEIs in general should receive public funding.

It is not our aim to discuss whether public funding is to be preferred to private funding or to other alternatives. Both solutions have advantages and disadvantages. In any case, public funding to $\mathrm{HE}$ still remains fundamental in many countries and seems to be the tool used by central governments to pursue their strategic objectives and steer HE systems.

\section{REFERENCES}

Barr, N. (1993). Alternative funding resources for higher education.
The Economic Journal, 103, 718-728. doi:10.2307/2234544

Barry, J., Chandler, J., \& Clark, H. (2001). Between the ivory tower and the academic assembly line. Journal of Management Studies, 38, 87-101. doi:10.1111/1467-6486.00229

Butler, L. (2003). Explaining Australia's increased share of ISI publications-The effect of a funding formula based on publication counts. Research Policy, 32, 143-155. doi:10.1016/S0048-7333(02)00007-0

Caraça, J., Conceição, P., \& Heitor, M. V. (1998). A contribution toward a methodology for university public funding. Higher Education Policy, 11, 37-57. doi:10.1016/S0952-8733(97)00026-3

Clark, B. R. (1983). The higher education system. Academic organization in cross-national perspective. Berkeley, LA: University of California Press.

Conceição, P., Heitor, M. V., \& Oliveira, P. M. (1998). Expectations for the university in the knowledge-based economy. Technological Forecasting and Social Change, 58, 203-214. doi:10.1016/S0040-1625(98)00018-3

Czarniawska, B., \& Genell, K. (2002). Gone shopping? Universities on their way to the market. Scandinavian Journal of Management, 18, 455-474. doi:10.1016/S0956-5221(01)00029-X

Etzkowitz, H. (2003). Research groups as "quasi-firms": The invention of the entrepreneurial university. Research Policy, 32, 109-121. doi:10.1016/S0048-7333(02)00009-4

Etzkowitz, H., Webster, A., Gebhardt, C., \& Terra, B. R. C. (2000). The future of the university and the university of the future: Evolution of the ivory tower to entrepreneurial paradigm. Research Policy, 29, 313-330. doi:10.1016/S0048-7333(99)00069-4

Eurostat, E. (2012). Key data on education in Europe 2012. Brussels: European Commission-Education, Audiovisual and Culture Executive Agency.

Eurydice (2008). Higher education governance in Europe. Policies, structures, funding and academic staff. Brussels: Eurydice, European Commission, Education and Culture DG.

Eurydice (2012). Modernisation of higher education in Europe. Funding and the social dimension 2011. Brussels: European Commission -Education, Audiovisual and Culture Executive Agency.

Galbraith, P. L. (1998). System dynamics and university management. System Dynamics Review, 14, 69-84. doi:10.1002/(SICI) 1099-1727(199821)14:1<69::AID-SDR139>3.0.C $\mathrm{O} ; 2-\mathrm{T}$

Geuna, A. (2001). The Changing rationale for European university research funding: Are there negative unintended consequences? Journal of Economic Issues, XXXV, 607-632.

Johnstone, D. B. (2004). The economics and politics of cost sharing in higher education: Comparative perspectives. Economics of Education Review, 23, 403-410. doi:10.1016/j.econedurev.2003.09.004

Liefner, I. (2003). Funding, resource allocation, and performance in 


\section{F. BARNABÈ}

higher education systems. Higher Education, 46, 469-489. doi:10.1023/A:1027381906977

Mazza, C., Quattrone, P., \& Riccaboni, A. (Eds.) (2008). European universities in transition: Issues, models and cases. Cheltenham: Edward Elgar Publishing Limited.

OECD (2009). Education at a glance 2009: OECD indicators. Paris: OECD Publishing.

OECD (2011). Education at a glance 2011: OECD indicators. Paris: OECD Publishing.

OECD/OCDE (2009). Main science and technology indicators, Volume 2009, Issue 1. Paris: OECD Publishing.
Reponen, T. (1999). Is leadership possible at loosely coupled organizations such as universities? Higher Education Policy, 12, 237-244. doi:10.1016/S0952-8733(99)00013-6

Scott, C. (2003). Controlling the campus. Risk \& Regulation, 5, 9.

Trow, M. (1994). Managerialism and the academic profession: The case of England. Higher Education Policy, 7, 11-18. doi:10.1057/hep.1994.13

Wasser, H., \& Picken, R. (1998). Changing circumstances in funding public universities: A comparative view. Higher Education Policy, 11, 29-35. doi:10.1016/S0952-8733(97)00025-1 